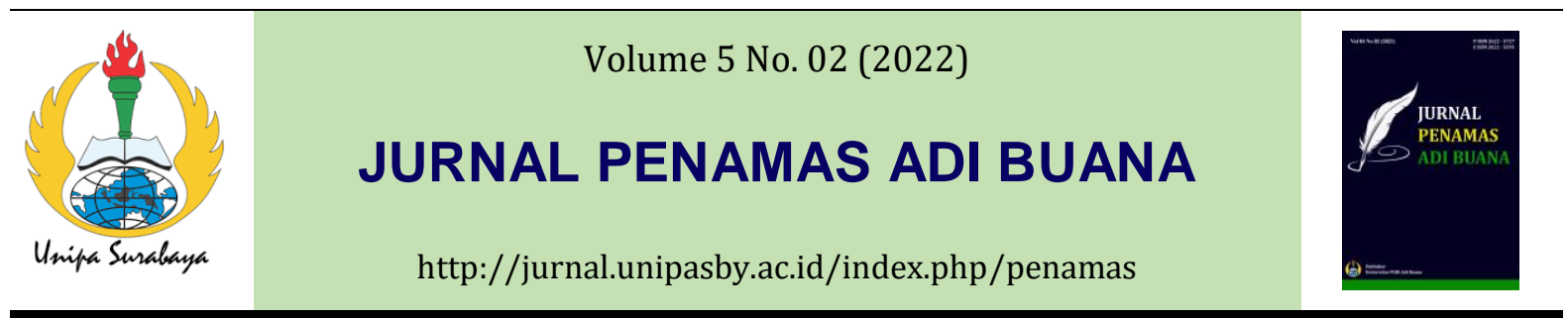

\title{
PENERAPAN UTILITAS SOLAR CELL SEBAGAI PENDUKUNG KONSEP SMART CITY DI KELURAHAN DUKUH MENANGGAL KOTA SURABAYA
}

\author{
Moch. Shofwan ${ }^{1 *}$, Annisa Budhiyani Tribhuwaneswari ${ }^{1}$, Suning ${ }^{1}$, A.A. Sagung Alit ${ }^{1}$ \\ Widyastuty $^{1}$, Linda Dwi Rohmadiani ${ }^{1}$, Siti Nuurlaily Rukmana ${ }^{1}$
}

${ }^{1}$ Program Studi Perencanaan Wilayah dan Kota, Fakultas Teknik, Universitas PGRI Adi Buana Email : shofwan.moch@unipasby.ac.id

\begin{abstract}
Informasi Artikel Abstrak
Kata kunci:

Utilitas, Solar Cell, Smart City.

Diterima: $15-10-2021$

Disetujui: 05-01-2022

Dipubikasikan: 31-012022

Kelurahan Dukuh Menanggal merupakan sebuah wilayah yang memiliki posisi perbatasan antara Kota Surabya dengan Sidoarjo ini menjadi destinasi favorit para masyarakat desa yang ingin memperbaiki kehidupannya dari segi ekonomi, pendidikan maupun sosial. Berbagai fasilitas pendukung tentunya juga disiapkan untuk menunjang kondisi perkembangan kawasan perkotaan tersebut. Sehingga berdasarkan isu ini, maka dibutuhkan penerapan utilitas solar cell sebagai pendukung konsep smart city di Kelurahan Dukuh Menanggal Kota Surabaya. Solusi yang ditawarkan dalam kegiatan program PKM ini adalah melakukan sosialisasi terkait penerapan utilitas solar cell sebagai pendukung konsep smart city di Kelurahan Dukuh Menanggal Kota Surabaya. Hasil dari kegiatan PKM ini yaitu ada pengetahuan yang meningkat bagi masyarakat terhadap pengetahuannya mengenai utilitas solar cell khususnya terkait pertanyaan pengenalan solar cell, fungsi solar cell, dan manfaat solar cell yaitu meningkat sebesar $50 \%$, namun pada pertanyaan kebijakan pemerintah dan sosialisasi dari instansi lain hasilnya stagnan tidak ada perubahan atau peningkatan persentase jawaban dari responden.
\end{abstract}

\section{Keywords :}

Utilities, Solar Cell, Smart City.

\section{Abstract}

Dukuh Menanggal Village is an area that has a border position between Surabya City and Sidoarjo, it is a favorite destination for village people who want to improve their lives in terms of economy, education and social. Various supporting facilities are of course also prepared to support the development conditions of the urban area. So based on this issue, it is necessary to implement the solar cell utility as a supporter of the smart city concept in Dukuh Menanggal Village, Surabaya City. The solution offered in this PKM program activity is to disseminate information related to the application of solar cell utilities as a supporter of the smart city concept in Dukuh Menanggal Village, Surabaya City. The result of this PKM activity is that there is increased knowledge for the community regarding their knowledge of the utility of solar cells, especially related to questions regarding the introduction of solar cells, the function of solar cells, and the 
benefits of solar cells, which is increased by $50 \%$, but on questions of government policy and socialization from other agencies the results are stagnant there is no change or increase in the percentage of answers from respondents.

\section{PENDAHULUAN}

Kelurahan Dukuh Menanggal secara administratif terletak di Kecamatan Gayungan Kota Surabaya (BPS Kota Surabaya, 2019), dimana berdekatan dengan kampus II Universitas PGRI Adi Buana, Surabaya (Gambar 1.). Jarak antara kelurahan dengan kampus Universitas PGRI Adi Buana Surabaya (UNIPA) \pm 300 meter. Berikut merupakan batas administrasi Kelurahan Dukuh Menanggal, yaitu

$$
\begin{array}{ll}
\text { Sebelah Utara } & \text { : Kelurahan Dukuh Menangga } \\
\text { Sebelah Timur } & : \text { Kelurahan Siwalankerto } \\
\text { Sebelah selatan } & : \text { Kelurahan Bungurasih } \\
\text { Sebelah Barat } & : \text { Kelurahan Sepanjang }
\end{array}
$$

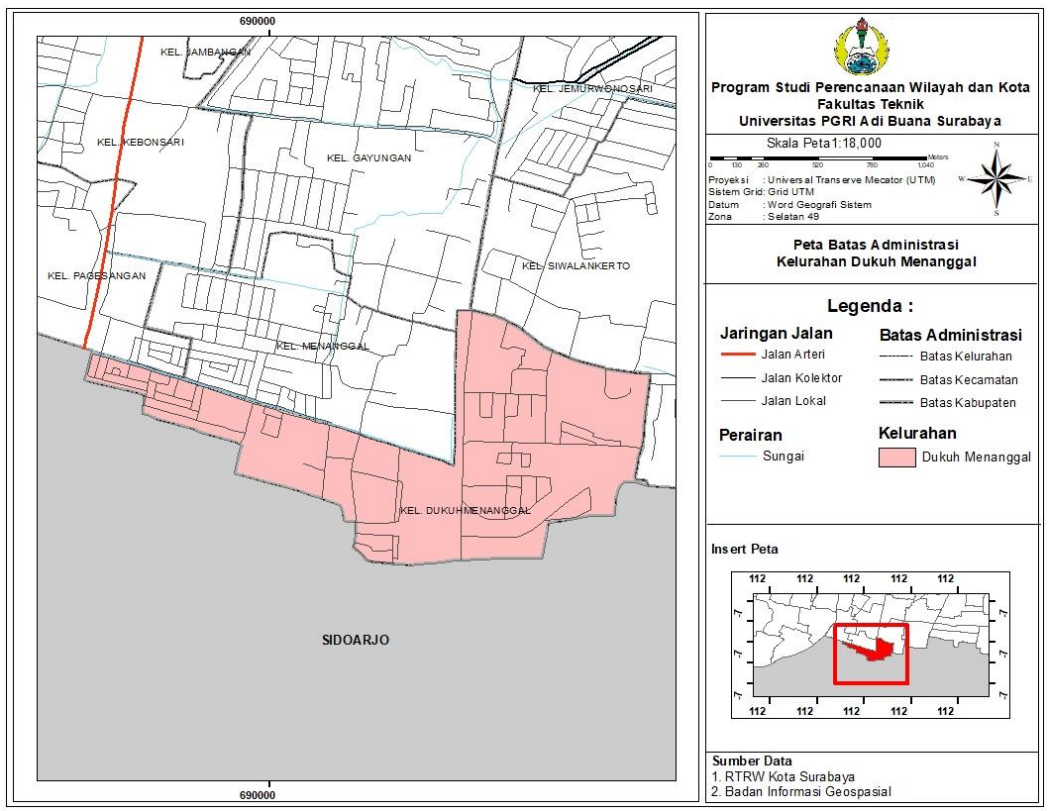

Gambar 1. Peta Administrasi Kelurahan Dukuh Menanggal

Berdasarkan data eksisting, Kelurahan Dukuh Menanggal Kecamatan Gayungan Kota Surabaya memiliki luas105.967 $\mathrm{Ha}$ atau $10,6 \mathrm{Km}^{2}$ dengan $31 \mathrm{RT}$ dan $9 \mathrm{RW}$. Jumlah penduduk pada Tahun 2019 sebesar 8.937 jiwa dengan kepadatan penduduk 8 jiwa/ $/ \mathrm{Km}^{2}$. Jumlah penduduk menurut usia berdasarkan data BPS Tahun 2000, terbanyak pada kelas 19 tahun keatas. Jumlah penduduk menurut tingkat pendidikan terakhir terbesar pada kelas SMA dan Universitas (Sarjana 
S1, S2), karena wilayah kelurahan dikelilingi oleh perguruan tinggi. Lokasi wilayah yang strategis menyebabkan penduduk kategori migrasi keluar dan masuk sangat besar hilirisasinya. Jenis pekerjaan penduduk Kelurahan Dukuh Menanggal didominasi sebagai karyawan baik swasta maupun ASN. Jenis penggunaan lahan berupa pemukiman, perkantoran, perdagangan dan jasa, ruang terbuka hijau, pendidikan dan peribadatan. Jenis penggunaan lahan di Kelurahan Dukuh Menanggal didominasi oleh permukiman seperti pada Gambar 2 dan 3.

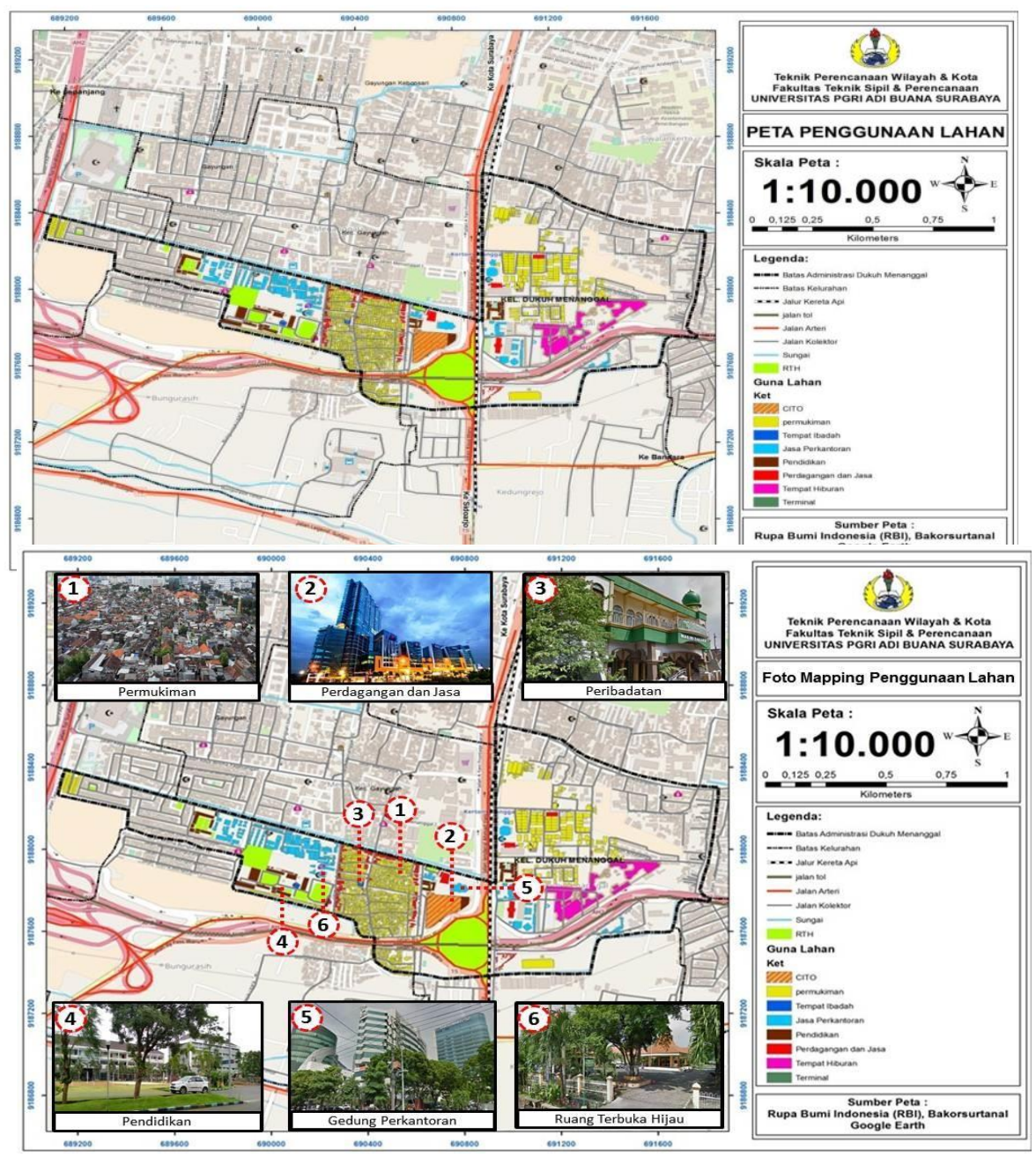

\section{Gambar 3. Foto Mapping Penggunaan Lahan Kelurahan Dukuh Menanggal}

Kelurahan Dukuh Menanggal merupakan sebuah wilayah yang memiliki posisi perbatasan antara Kota Surabya dengan Sidoarjo ini menjadi destinasi favorit para masyarakat desa yang ingin memperbaiki kehidupannya dari segi ekonomi, pendidikan maupun sosial. (http://digilib.uinsby.ac.id/16608/55/Bab\%201.pdf diakses 11 Februari 2021). Berbagai fasilitas pendukung tentunya juga disiapkan untuk menunjang kondisi perkembangan kawasan perkotaan tersebut. Sehingga berdasarkan isu ini, maka dibutuhkan penerapan utilitas solar cell sebagai pendukung konsep smart city di Kelurahan Dukuh Menanggal Kota Surabaya. 


\section{METODE}

Metode pelaksanaannya yaitu dengan melakukan grounded di Kelurahan Dukuh Menanggal. Kelompok karang taruna, PKK dan aparat kelurahan diundang untuk berkumpul di balai kelurahan untuk kemudian diberikan materi tentang penerapan utilitas solar cell sebagai pendukung konsep smart city di Kelurahan Dukuh Menanggal Kota Surabaya. Skematis Rancangan Pelaksanaan Program Pengabdian pada masyarakat adalah pada Gambar 3.1

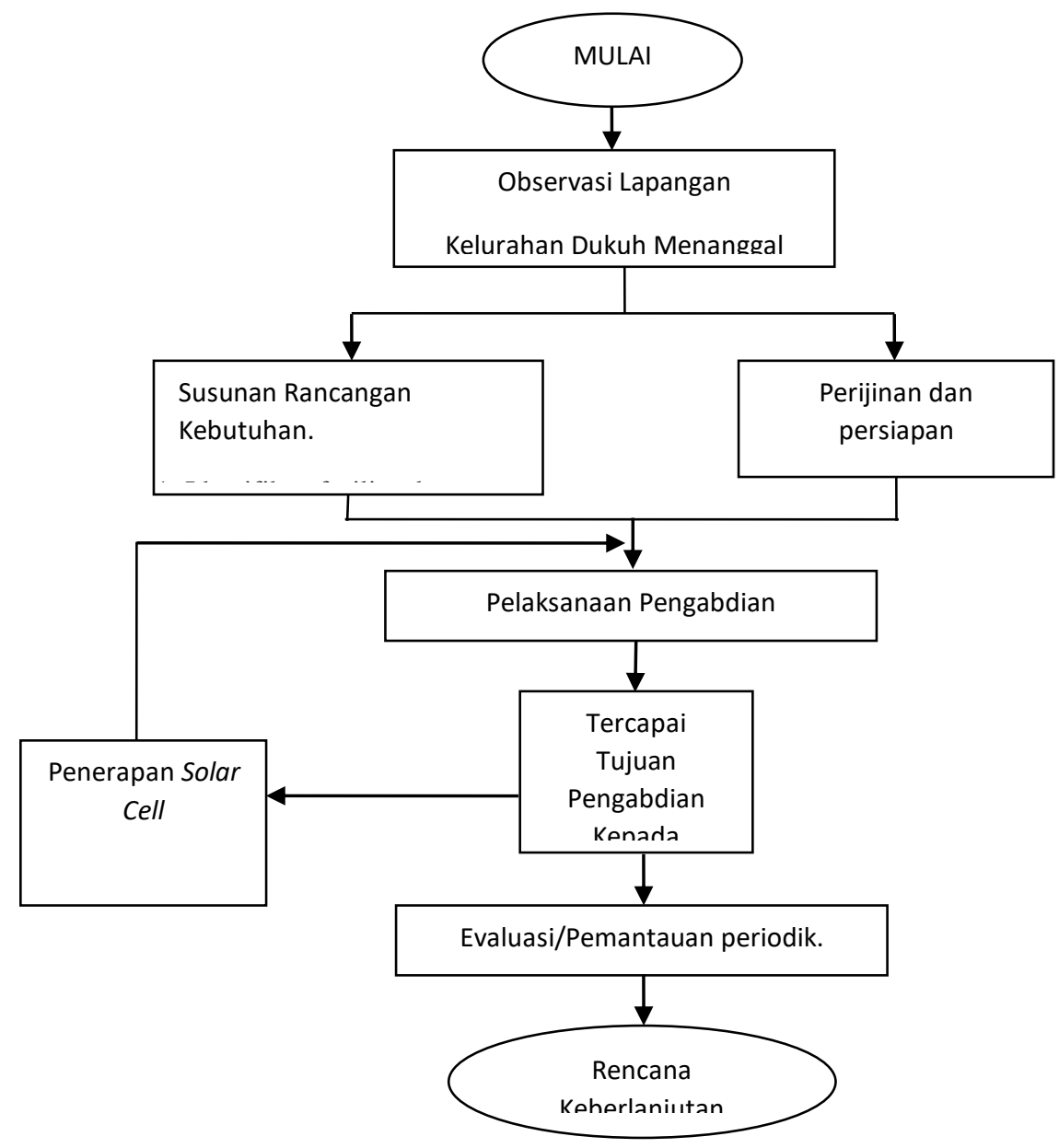

\section{Gambar 4. Skema Pelaksanaan PKM Program Studi Perencanaan Wilayah dan Kota}

Adapun Langkah-langkah yang dilaksanakan yaitu:

1. Perangkaian Solar Cell

Langkah pertama yaitu melakukan identifikasi fasilitas Kawasan di Kelurahan Dukuh Menanggal yang dapat diterapkan utilitas solar cell sebagai pendukung daya hemat energi listrik untuk penunjang smart city.

2. Kegiatan perangkaian solar cell tersebut meliputi :

a. Survey lapangan;

b. Konsultasi dan musyawarah dengan Perangkat Kelurahan; 
c. Pembelian material seperti utilitas solar cell, tiang besi, dan lain-lain;

d. Pemasangan pada titik yang ditentukan;

e. Dokumentasi.

\section{HASIL DAN PEMBAHASAN}

Hasil pelaksanaan PKM yang telah dilaksanakan oleh tim dosen adalah:

1. Sosialisasi pemanfaatan utilitas solar cell

a) Kondisi awal

Kegiatan pemanfaatan utilitas solar cell masih belum dilakukan oleh masyarakat di Kelurahan Dukuh Menanggal Kota Surabaya. Melihat kondisi tersebut tim pelaksana PKM dosen menawarkan adanya kegiatan pemanfaatan utilitas solar cell, sebagai upaya konsep smart city di Kelurahan Dukuh Menanggal.

b) Kondisi akhir

Setelah dilakukan kegiatan penyuluhan mengenai bagaimana pemanfaatan utilitas solar cell, alur prosesnya, serta sebagai penunjang konsep smart city yang ada di Kelurahan Dukuh Menanggal, maka warga sudah mengetahui pentingnya utilitas solar cell sebagai penunjang konsep smart city di Kelurahan Dukuh Menanggal Kota Surabaya

c) Serah terima utilitas solar cell

Dalam kegiatan sosialisasi dan penyuluhan mengenai penentuan pemanfaatan utilitas solar cell secara teori sudah diberikan materi saat paparan. Selanjutnya dari tim PKM Dosen Perencanaan Wilayah dan Kota memberikan utilitas solar cell. Harapannya warga mengetahui pemanfaatan utilitas solar cell yang ada di Kelurahan Dukuh Menanggal guna menunjang konsep smart city.

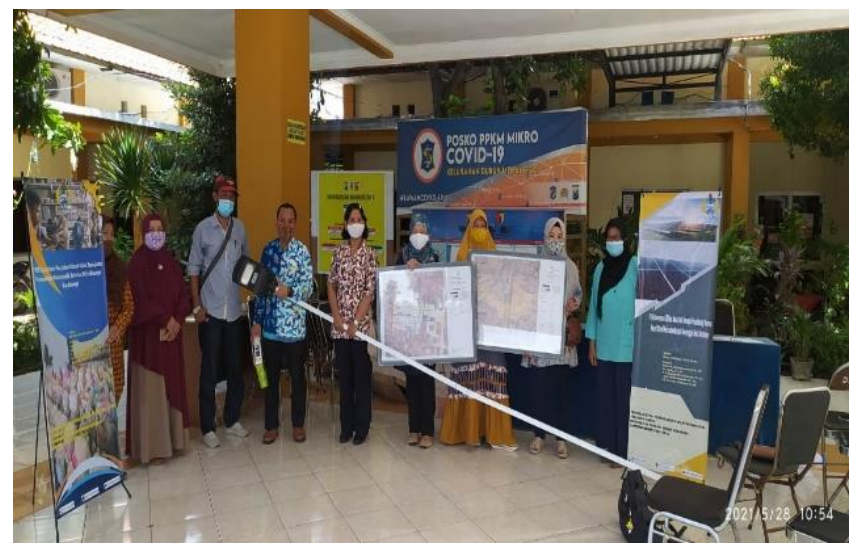

Gambar 5. Serah Terima Utilitas Solar Cell

2. Hasil kajian terhadap pemahaman masyarakat mengenai utilitas solar cell.

Kegiatan ini dilakukan dengan dua tahap yaitu: 
Tahap pertama: Tim dosen memberikan kuesioner pre -test kepada peserta PKM berupa pertanyaan-pertanyaan seputar utilitas solar cell dengan tujuan untuk mengetahui sejauh mana pemahaman mereka terhadap pemanfaatan utilitas solar cell sebelum ada penyuluhan.

Tahap kedua: Tim dosen memberikan kuesioner post -test kepada peserta PKM berupa pertanyaan-pertanyaan seputar utilitas solar cell dengan tujuan untuk mengetahui sejauh mana pemahaman mereka terhadap pemanfaatan utilitas solar cell setelah diberikan penyuluhan. Hasil analisis pre -test dan post - test disajikan pada Tabel 5.1 (jawaban kuesioner pre-test dan posttest), tabel 5.2 (hasil persentase pre-test dan post - test)

Tabel 1. Hasil Kuesioner Sebelum dan Sesudah Dilakukan Penyuluhan dan Pelatihan

\begin{tabular}{|c|c|c|c|c|c|c|c|}
\hline \multicolumn{4}{|c|}{ PRE-TEST } & \multicolumn{4}{|c|}{ POST-TEST } \\
\hline \multirow[t]{2}{*}{ No } & \multirow[t]{2}{*}{ Pertanyaan } & \multicolumn{2}{|c|}{$\begin{array}{c}\text { Presentase } \\
(\%)\end{array}$} & \multirow{2}{*}{ No } & \multirow{2}{*}{ Pertanyaan } & \multicolumn{2}{|c|}{$\begin{array}{c}\text { Presentase } \\
(\%)\end{array}$} \\
\hline & & $\mathbf{Y a}$ & Tidak & & & Ya & Tidak \\
\hline 1. & $\begin{array}{l}\text { Apakah warga masyarakat } \\
\text { Kelurahan Dukuh Menanggal } \\
\text { mengenal tentang solar cell? }\end{array}$ & 5 & 5 & 1. & $\begin{array}{l}\text { Apakah warga masyarakat } \\
\text { Kelurahan Dukuh Menanggal } \\
\text { mengenal tentang solar cell? }\end{array}$ & 10 & 0 \\
\hline 2. & $\begin{array}{l}\text { Apakah warga masyarakat } \\
\text { Kelurahan Dukuh Menanggal } \\
\text { mengetahui apa fungsi solar cell? }\end{array}$ & 5 & 5 & 2. & $\begin{array}{l}\text { Apakah warga masyarakat } \\
\text { Kelurahan Dukuh Menanggal } \\
\text { mengetahui apa fungsi solar } \\
\text { cell? }\end{array}$ & 10 & 0 \\
\hline 3. & $\begin{array}{l}\text { Apakah masyarakat Kelurahan } \\
\text { Dukuh Menanggal mengetahui } \\
\text { manfaat dari solar cell? }\end{array}$ & 5 & 5 & 3. & $\begin{array}{l}\text { Apakah masyarakat Kelurahan } \\
\text { Dukuh Menanggal mengetahui } \\
\text { manfaat dari solar cell? }\end{array}$ & 10 & 0 \\
\hline 4. & $\begin{array}{l}\text { Sejauh mana keterlibatan } \\
\text { pemerintah dalam menggerakkan } \\
\text { kebijakan penggunaan solar cell? }\end{array}$ & 0 & 10 & 4. & $\begin{array}{l}\text { Sejauh mana keterlibatan } \\
\text { pemerintah dalam menggerakkan } \\
\text { kebijakan penggunaan solar cell? }\end{array}$ & 0 & 10 \\
\hline 5. & $\begin{array}{l}\text { Apakah sudah ada instansi atau } \\
\text { universitas lain yang memberikan } \\
\text { sosialisasi penerapan solar cell di } \\
\text { Kelurahan Dukuh Menanggal? }\end{array}$ & 0 & 10 & 5. & $\begin{array}{l}\text { Apakah sudah ada instansi atau } \\
\text { universitas lain yang } \\
\text { memberikan sosialisasi } \\
\text { penerapan solar cell di } \\
\text { Kelurahan Dukuh Menanggal? }\end{array}$ & 0 & 10 \\
\hline
\end{tabular}

Sumber: Hasil analisis, 2021 
Tabel 2. Hasil Persentase Sebelum dan Sesudah Dilakukan Penyuluhan dan Pelatihan

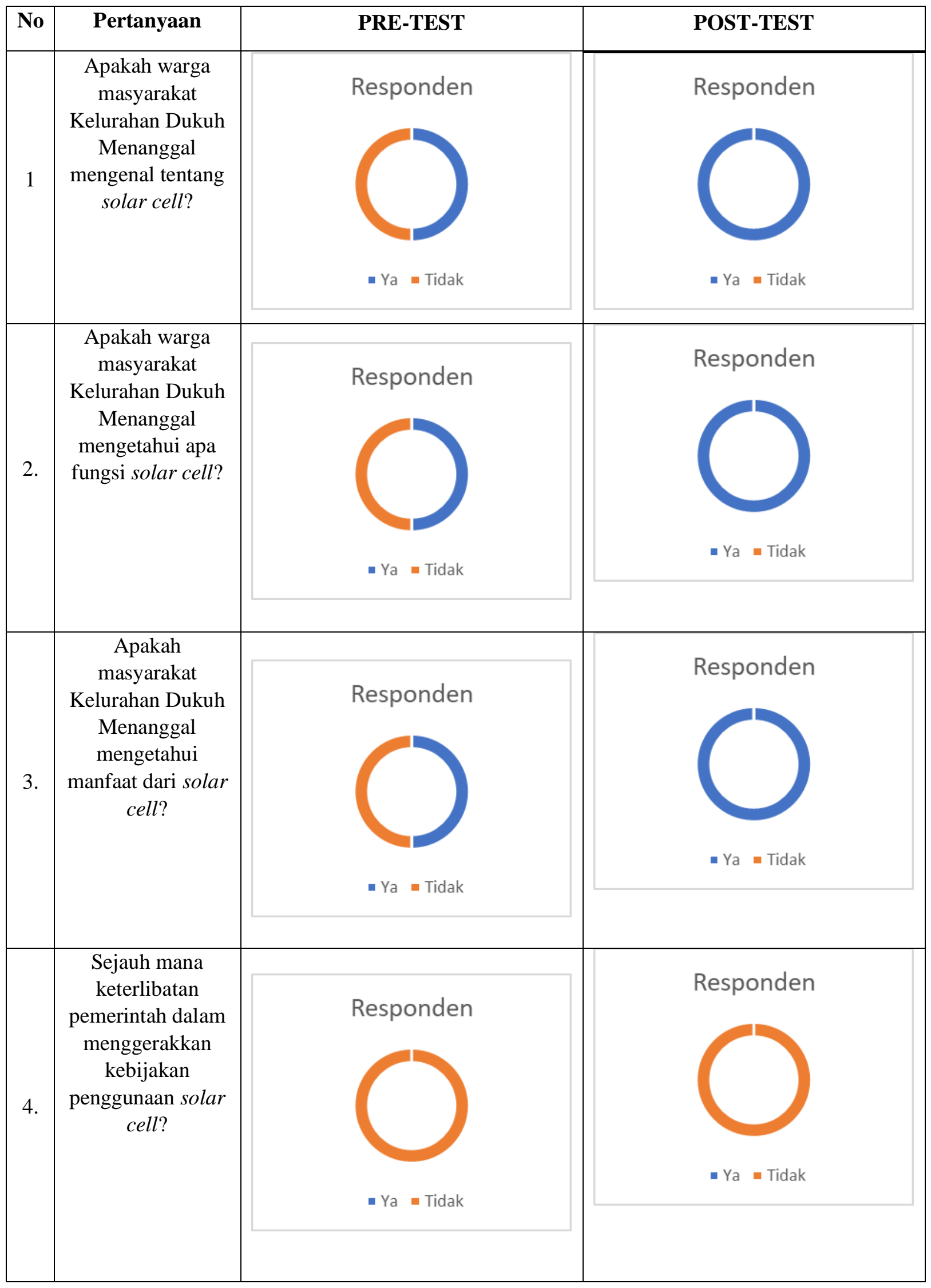




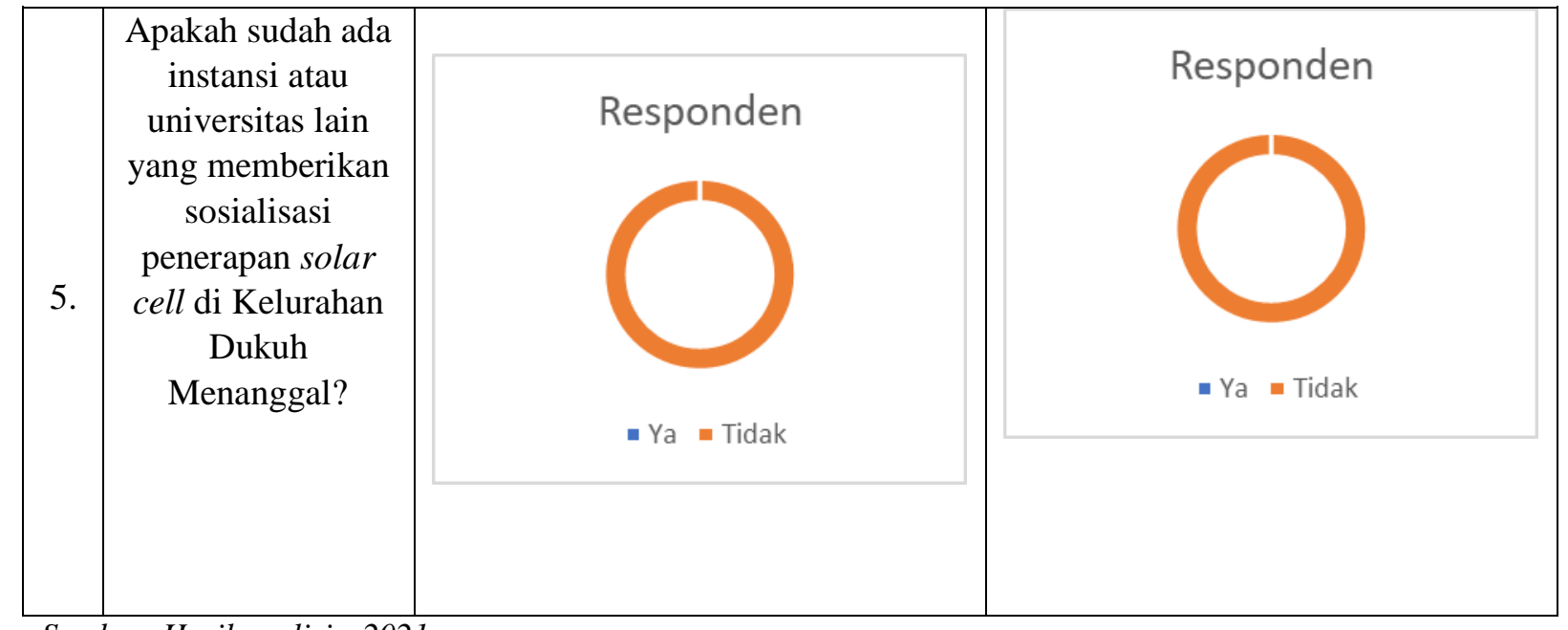

Sumber: Hasil analisis, 2021

Hasil analisis yang terdapat pada Tabel 5.1 dan Tabel 5.2 sebelum dilakukannya penyuluhan dan pelatihan, maka ada pengetahuan yang meningkat bagi masyarakat terhadap pengetahuannya mengenai utilitas solar cell khususnya terkait pertanyaan pengenalan solar cell, fungsi solar cell, dan manfaat solar cell yaitu meningkat sebesar $50 \%$, namun pada pertanyaan kebijakan pemerintah dan sosialisasi dari instansi lain hasilnya stagnan tidak ada perubahan atau peningkatan persentase jawaban dari responden.

\section{KESIMPULAN}

Pelaksanaan PKM dengan judul "PKM Penerapan Utilitas Solar Cell Sebagai Pendukung Konsep Smart City di Kelurahan Dukuh Menanggal Kota Surabaya" berjalan dengan baik dan lancar. Hasil yang diperoleh dari pelaksanaan ini adalah utilitas solar cell Kelurahan Dukuh Menanggal terpenuhi dengan baik sesuai denga apa yang dikehendaki oleh pihak kelurahan dan kader penggerak. Maka adanya utilitas solar cell ini menjadikan masyarakat secara mandiri dapat mengetahui pemanfaatan utilitas solar cell sebagai pendukung konsep smart city di Kelurahan Dukuh Menanggal Kota Surabaya.

\section{DAFTAR PUSTAKA}

Badan Pusat Statistik Kota Surabaya Tahun 2019.

Budiyanto, dan Fadliondi. (2017). The Improvement of Solar Cell Output Power Using Cooling and Reflection from Mirror. International Journal of Power Electronics and Drive System (IJPEDS). Vol. 8, No. 3, September 2017, pp. 1320 1326.

Handayani, NA, dan Ariyanti, D. (2012). Potency of Solar Energy Applications in Indonesia. Int. Journal of Renewable Energy Development 1 (2) 2012: 33-38.

http://digilib.uinsby.ac.id/16608/55/Bab\%201.pdf diakses 11 Februari 2021

http://eprints.polsri.ac.id/1109/3/BAB\%20II.pdf, diakses 10 Februari 2021

digilib.its.ac.id/public/ITS-Master-13287-Chapter1I.pdf, diakses 10 Februari 2021

http://imall.iteadstudio.com, diakses tanggal 10 Februari 2021 
http://imall.iteadstudio.com, diakses tanggal 10 Februari 2021

http://www.tradeindia.com/fp882650/144W-Thin-Film-Amorphous-Silicon-Flexible

SolarPanels.html, diakses tanggal 10 Februari 2021

www.design-impact.org, diakses tanggal 10 Februari 2021 